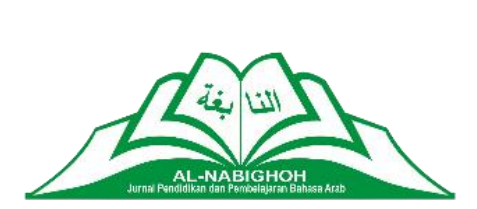

\title{
AKUISISI BAHASA ARAB SANTRI PONDOK PESANTREN MADINAH KARYA TANI LAMPUNG TIMUR
}

\author{
J. Sutarjo ${ }^{*}$, Novita Rahmi ${ }^{2}$, Dian Ekawati ${ }^{3}$, Nawang Wulandari ${ }^{4}$ \\ 1,2,3,4 Institut Agama Islam Negeri Metro, Indonesia
}

\section{Article Info}

\section{Article History:}

Received: September 2021

Revised: December 2021

Accepted: December 2021

Published: December 2021

\section{*Corresponding Author:}

Name: J. Sutarjo

Email:

j.sutarjo@metrouniv.ac.id

\section{Abstract}

One of the Islamic boarding schools that teaches Arabic with divine and active competence is Madina Islamic Boarding School, which is located in Karya Tani Labuhan Meringgai, East Lampung. Many aspects certainly support the success of the institution that implements and develops Arabic language learning This reserch used a psycholinguistic perspective, especially language acquisition. This is because in fact the graduates of the Medina Islamic Boarding School have active Arabic language competence. It is very interesting to conduct a study to find out about the language acquisition of the students at the Islamic boarding school. This study describes; 1) Arabic language learning process, 2) Arabic language acquisition process, 3) acquisition theory relevance in a psycholinguistic perspective with the Arabic language learning process, and 4) strengths and weaknesses of the Arabic acquisition process at the Madinah Islamic Boarding School. This research is a qualitative field research. For data collection using the observation method, interview method, and documentation method. From this study, it is hoped that it will become one of the references in developing Arabic learning. From the results of the study, it can be concluded that the acquisition of foreign languages, especially Arabic, for the students of the modern Islamic boarding school Madinah, was carried out through formal and naturalistic presentations. For the factors that affect the Arabic language acquisition process, there are obstacles to the motivation of students which also affect the Arabic language environment which is less conducive. As for the age factor, the presentation of learning and the first language of the students have been conditioned and in accordance with the ideal foreign language acquisition process in a psycholinguistic perspective. The age of children to adolescents is the ideal age to carry out the process of acquiring foreign languages, presenting complete learning in a formal and naturalistic manner, as well as conditioning the first language by speaking Arabic in the first year of students studying at Islamic boarding schools.

Copyright (c) 2021, J. Sutarjo et al

This is an open-access article under the CC-BY-SA license

\section{مستخلص البحث}

$$
\begin{aligned}
& \text { إحدى المدارس الداخلية الإسلامية التي تدرس اللغة العربية بكفاءة إلهية وفاعلة هي مدرسة المدينة الداخلية الإسلامية ، التي تقع في كاريا } \\
& \text { تاني لبوهان ميرينجاي ، شرق لامبونج. هناك العديد من الجوانب التي تدعم بالتأكيد نجاح المؤسسة التي تنفذ وتطور تعلم اللغة العربية. } \\
& \text { استخدم هذا البحث منظورًا نفسيًا لغويًا ، لا سيما اكتساب اللغة (اكتساب اللغة). هذا لأن خريجي المدرسة الداخلية الإسلامية بالمدينة } \\
& \text { يتمتعون بكفاءة نشطة في اللغة العربية. من المثير للاهتمام إجراء دراسة لمعرفة المزيد عن اكتساب الطلاب للغة في المدرسة الداخلية } \\
& \text { الإسلامية. تصف هذه الدراسة ؛ 1) عملية تعلم اللغة العربية ، ؟) عملية اكتساب اللغة العربية (اكتساب اللغة العربية) ، ؟r) علاقة نظرية } \\
& \text { الاكتساب من منظور لغوي نفسي بعملية تعلم اللغة العربية ، ع) نقاط القوة والضعف في عملية اكتساب اللغة العربية في مدرسة المدينة } \\
& \text { الداخلية الإسلامية - تاني لابوهان مارينجاي. هذا البحث هو بحث ميداني نوعي. لجمع البيانات باستخدام طريقة الملاحظة وطريقة }
\end{aligned}
$$




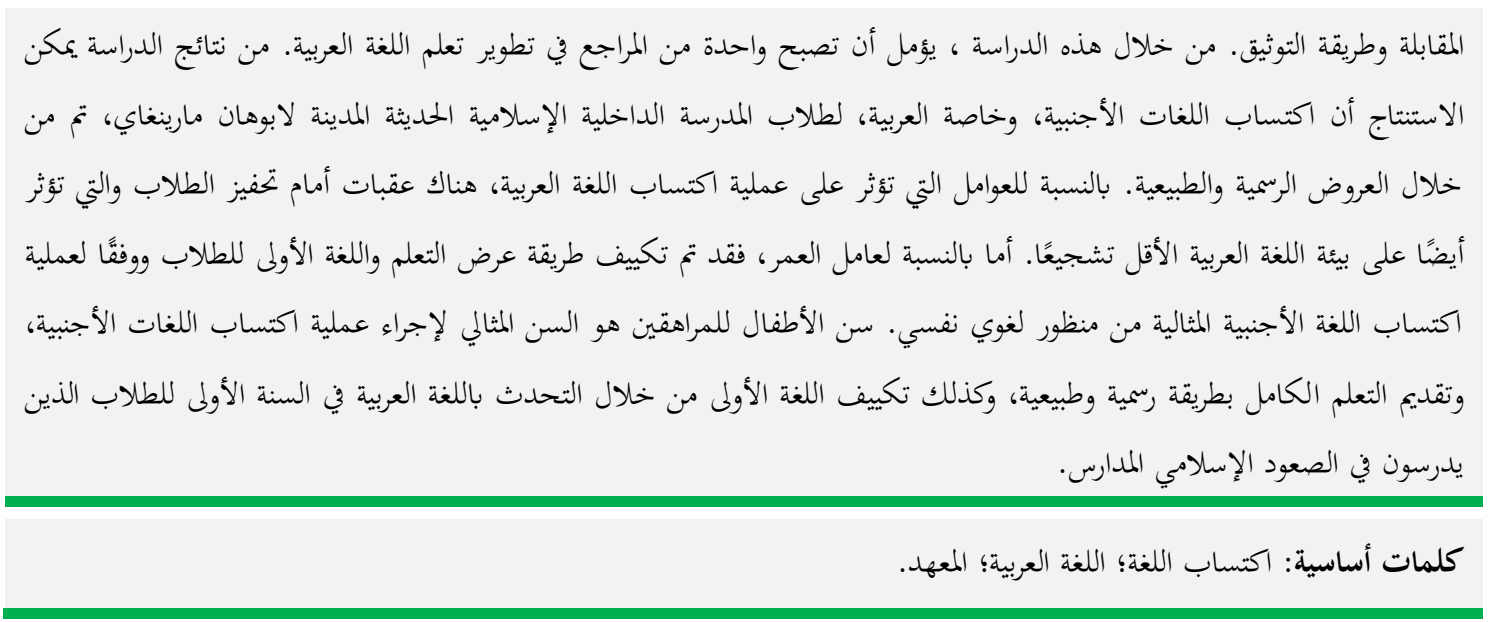

\section{Pendahuluan}

Bahasa Arab merupakan bahasa asing di negara Indonesia. Mayoritas penduduk Indonesia yang beragama Islam tidak asing dengan bahasa yang digunakan dalam kitab suci al Qur'an. Dari penduduk Islam sangat sedikit yang dapat menggunakan bahasa Arab sebagai bahasa komunikasi. Hingga saat ini dapat dikatakan bahwa sebagian besar pembelajaran bahasa Arab berorientasi pada kompetensi pemahaman bahasa dari sisi linguistik yang bersifat pasif. Sebagian besar umat Islam memakai bahasa Arab, baru sebatas untuk melaksanakan ibadah.

Hingga saat ini tampak pengajaran bahasa arab kian berkembang cukup pesat. Bahasa Arab banyak diperkenalkan sejak dini yaitu mulai jenjang pendidikan PUD dan TK. Jika sebelumnya bahasa Arab hanya diajarkan di sekolahsekolah bercirikan Islam seperti MI, MTs, MA dan PTAI saat ini bahasa Arab sudah merambah ke lembaga-lembaga pendidikan secara umum, baik SD, SMP, SMA maupun SMK. Hal ini tentu merupakan fenomena yang cukup menggembirakan dalam dunia pembelajaran bahasa Arab.

Kebanggaan bagi bangsa Indonesia terkait dengan pengembangan bahasa Arab adalah bahwa Indonesia memiliki ribuan lembaga Pondok Pesantren yang dapat dipastikan mengajarkan bahasa Arab. Kendatipun tradisi pesantrenpesantren di Indonesia mayoritas mengajarkan bahasa arab secara pasif, sejalan dengan perkembangannya saat ini sudah menjamur lembaga-lembaga pondok pesantren yang mengembangkan pembelajaran bahasa Arab dari yang hanya bersifat pasif ke arah pembelajaran bahasa Arab pasif dan juga aktif.

Di lampung lembaga Pondok Pesantren juga mendapat dukungan yang penuh dari masyarakat. Hampir setiap lembaga Pondok Pesantren sangat diminati masyarakat dengan mempercayakan putra-putrinya untuk dididik di lembagalembaga Pondok Pesantren. Baik pesantren yang bersifat salafi, modern ataupun pesantren khusus hafalan al Qur'an (Tahfidz al Qur'an). Apapun corak/karakter setiap Pondok Pesantren yang ada sudah pasti bahasa Arab diajarkan di lembagalembaga tersebut. 
Sejalan dengan tuntutan kompetensi berbahasa Arab saat ini. Bahwa kompetensi berbahasa Arab tidak cukup sebatas berbahasa Arab secara pasif karna tuntun kerja ke timur tengah dan yang lebih penting melanjutkan pendidikan ke jenjang yang lebih tinggi ke negara-negara Arab. Mau tidak mau paradigma pembelajaran bahasa Arab saat ini mengalami pergeseran. Pergeseran paradigma dalam pembelajaran bahasa Arab di pesantren-pesantren kiranya mengakibatkan dampat sebutan bagi karakteristik Pondok Pesantren itu sendiri. Saat ini di Indonesia menyebut Pondok Pesantren yang mempertahankan tradisi lama yang menjadikan bahasa Arab sebagai bahasa pasif dengan sebutan "Pondok Pesantren Salaf" dan yang menjadikan bahasa Arab sebagai bahasa aktif dengan sebutan "Pondok Pesantren Modern". Tentu dengan ciri-ciri lain sebagai fokus pembelajarannya.

Salah satu Pondok Pesantren yang mengajarkan bahasa Arab dengan tuhuan kompetensi pasif dan aktif adalah Pondok Pesantren Madinah yang berlokasi di Karya Tani Lbuhan Meringgai lampung Timur. Pesantren ini boleh dikatakan berhasil dalam mengembangkan pembelajaran bahasa Arab. Hal ini tampak dari lulusan-lulusannya yang mengikuti perkuliahan di IAIN Metro khususnya di Program Studi Pendidikan Bahasa Arab (PBA). Kompetensi berbahasa arabnya baik pasif maupun aktif tampak mayoritas sangat baik. Hal itu tampak dalam mengikuti perkuliahan, ujian komprehensif dan munaqosyah ataupun. Kompetensi berbahasa Arab pasif dan aktifnya cukup berimbang.

Dari tahun ke tahun tampak lulusannya cukup menonjol khususnya di program studi Pendidikan bahasa Arab. Hal ini tentu menjadi sesuatu yang menarik dan penting untuk dikaji sehingga hasil kajiannya dapat dijadikan hazanah pengetahuan dan referensi penting yang dapat memeberikan kontribusi dalam pengembangan sistem pembelajaran bahasa Arab di era modern seperti saat ini.

Banyak aspek yang tentunya mendukung keberhasilan suatu lembaga yang melaksanakan dan mengembangkan pembelajaran bahasa Arab. Dalam penelitian ini akan menggunakan perspektif psikolinguistik khususnya akuisisi bahasa (Iktisaab al Lughah/Language acquisition). Hal ini karena pada kenyataannya lulusan-lulusan Pondok Pesantren Madinah memiliki kompetensi berbahasa Arab secara aktif. Sangat menarik untuk dilakukan studi untuk mengetahui tentang pemeroleh bahasa para santri di Pondok Pesantren tersebut.

Bahasa adalah simbol-simbol yang bersifat arbitrer $^{1}$ yang disepakati oleh suatu komunitas manusia untuk berkomunikasi dalam aktivitas sosial. Dalam kajian filsafat bahasa, bahasa dimengerti sebagai bunyi-bunyian yang digunakan

\footnotetext{
${ }^{1}$ Kata arbitrer sangat familier dalam kajian bahasa atau filsafat bahasa yang maksudnya adalah bahwa kemunculan simbol-simbol suatu bahasa pada umumnya muncul dengan begitu saja, tanpa disengaja ataupun melalui perumusan secara khusus. Antara kata dengan esensi yang disebut tidak harus ada hubungan satu sama lain namun disepakati oleh pengguna bahasa tersebut.
} 
oleh semua kelompok manusia untuk menyampaikan tujuan-tujuan mereka. ${ }^{2}$ Jika dilihat dari fungsinya, bahasa merupakan media dalam menjalin suatu pemahaman di antara manusia satu sama lain. ${ }^{3}$ Sehingga bahasa merupakan fenomena kehidupan manusia yang amat penting khususnya dalam interaksi sesama manusia. Tidak dapat dibayangkan apabila dalam kehidupan ini tidak ada bahasa yang dijadikan sebagai media untuk mengekspresikan diri, menyampaikan keinginan dan lain sebagainya.

Dalam filsafat bahasa disebutkan bahwa asal usul bahasa dalam sekelompok manusia penutur bahasa itu sendiri. Misalnya terkait dengan simbol-simbol kebahasaan baik yang bersifat lisan (bunyi) atau tulisan (tulis). Simbol-simbol itu tercetus atau muncul dari suatu kamunitas masyarakat, disepakati dan digunakan dalam interaksi komunikasi di antara mereka. ${ }^{4}$ Menurut Santoso dalam Sumanto bahasa adalah rangkaian bunyi yang dihasilkan oleh alat ucap manusia secara sadar. ${ }^{5}$

Jika dilihat dari fungsinya, bahasa adalah alat komunikasi yang digunakan manusia untuk berinteraksi dengan sesama. ${ }^{6}$ Keraf dalam Sujinah menjelaskan bahwa fungsi bahasa sebagai alat untuk mengekspresikan diri, sebagai alat untuk berkomunikasi, sebagai alat untuk mengadakan integrasi dan beradaptasi sosial dalam lingkungan atau situasi tertentu, dan alat untuk melakukan kontrol sosial.7 Sementara jika dilihat dari perkembangannya bahasa secara realitas berkembang sesuai dengan perkembangan manusia itu sendiri. ${ }^{8}$ Maka dapat dapat diinterpretasikan bahwa bahasa adalah simbol-simbol baik bunyi atau tulis yang berasal dari suatu komunitas penutur dan disepakati suatu komunitas manusia dan digunakan sebagai media dalam berkomunikasi antar mereka serta selalu berkembang seiring dengan perkembangan manusia itu sendiri.

Bahasa Arab adalah bahasa yang memiliki karakteristik khusus terkait dengan simbol-simbolnya, baik berupa simbol-simbol bunyinya dan juga simbolsimbol dalam bentuk tulis. Bahasa Arab merupakan bahasa yang digunakan dalam komunikasi di negara-negara kawasan Arab khususnya dan umat Islam di seluruh dunia pada umumnya. Dari aspek perkembangannya, dapat dikatakan bahwa bahasa ini merupakan bahasa yang berkembang sangat pesat dibandingkan

2 Jurji Zaidan, Al-Falsafah Al-Lughowiyah (Beirut: Daaru Al-Jiil, 1904), 11.

${ }^{3}$ Abdul Majid Sayid Ahmad Mansyur, Ilmu Al-Lughoh Al-Nafsi (Riyadh: Jami'ah Mulk Su'udi, 1982), 31.

${ }^{4}$ Zaidan, Al-Falsafah Al-Lughowiyah, 18.

${ }^{5}$ Edi Sumanto, "Hubungan Filsafat Dengan Bahasa," El-Afkar: Jurnal Pemikiran Keislaman Dan $\begin{array}{lllll}\text { Tafsir Hadis } & \text { 6, no. } & 1 & \text { (2017): }\end{array}$ https://ejournal.iainbengkulu.ac.id/index.php/elafkar/article/view/1236.

${ }^{6}$ A. Hidayat, "Bi'ah Lughowiyah (Lingkungan Berbahasa) Dan Pemerolehan Bahasa (Tinjauan Tentang Urgensi Lingkungan Berbahasa Dalam Pemerolehan Bahasa)," An-Nida' 37, no. 1 (2012): 35-44, http://ejournal.uin-suska.ac.id/index.php/Anida/article/view/311.

7 Sujinah, Bahasa Indonesia (Surabaya: UM Surabaya Pablishing, 2018), 6.

8 Acep Hermawan, Metodologi Pembelajaran Bahasa Arab (Bandung: Remaja Rosdakarya, 2011), 8 . 
bahasa-bahasa di dunia. ${ }^{9}$ Kompleksitas bahasa Arab sangat diakui mulai dari aspek fonologi, morfologi, sintaks hingga semantiknya. Hal ini mungkin merupakan salah satu alasan dipilihnya bahasa Arab sebagai bahasa firman Allah SWT. sebagaimana firman Allah ta'ala yang menyatakan bahwa Allah menurunkan al Qur'an dalam bahasa Arab tertera dalam surat Yusuf ayat 2:

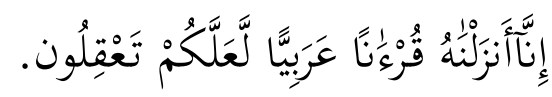

"Sesungguhnya kami turunkan al Qur'an dengan berbahasa Arab agar kalian memahaminya".

Bagi bangsa Indonesia yang mayoritas penduduknya beragama Islam bahasa Arab tentu menjadi sangat urgen dalam kehidupan. Hal ini dikarenakan beberapa hal sebagai berikut: 1) Bahasa Arab merupakan sarana utama dalam memahami agama Islam; sudah dimaklumi bahwa al Qur'an dan al Hadits pedoman utama umat Islam berbahasa Arab, penjelasan para ulama mengenai kandungan al Qur'an dan al Hadits banyak menggunakan bahasa Arab sebagai bahasa pengantar. Sehingga siapapun yang ingin memahami tentang ajaran Islam harus mengerti bahasa Arab dari berbagai aspeknya keilmuan yang berkaitan dengannya. 2) Bahasa Arab memiliki peranan penting dalam perkembangan ilmu pengetahuan; harus diakui bahwa sejarah membuktikan bahwa perkembangan filsafat dan berbagai ilmu pengetahuan banyak diprakarsai oleh ulama Islam yang tentunya telah mewariskan pemikirannya dengan menggunakan media bahasa Arab. 3) Bahasa Arab merupakan bahasa pergaulan dunia; selain bahasa arab sebagai salah satu bahasa PBB (Perserikatan Bangsa-Bangsa), banyak interaksi umat Islam yang membutuhkan bahasa Arab. Ketika menjalin hubungan kerja di berbagai bidang dengan sesama umat Islam antar negara dan juga dalam pelaksanaan ibadahibadah yang mempertemukan seluruh manusia di belahan dunia khususnya ibadah haji dan umroh. ${ }^{10}$

Akuisisi bahasa atau pemerolehan bahasa dalam bahasa Arab diistilahkan dengan sebutan iktisaab al lughah dan dalam bahasa Inggris dikenal dengan istilah language acquisition adalah proses yang berlangsung di dalam otak seseorang dalam memperoleh suatu bahasa. Mulanya istilah ini digunakan dalam proses pemeroleh bahasa pertama (bahasa ibu). ${ }^{11}$ Menurut Maksan dalam Suardi akuisi bahasa adalah suatu proses penguasaan bahasa yang dilakukan oleh seseorang secara tidak sadar, implisit dan informal. ${ }^{2}$ Adapun menurut Syamsul dalam

\footnotetext{
${ }^{9}$ Zaidan, Al-Falsafah Al-Lughowiyah, 27.

${ }^{10}$ Abdul Mu'in dan Dony Handriawan, "Pembelajaran Bahasa Arab Sebagai Bahasa Kedua," AlIttijaah 4, no. 2 (2012): 144.

${ }^{11}$ Bahasa ibu adalah bahasa yang awal mula dipelajari seorang anak baik berasal dari orang tua atau dari lingkungan dimana dia tinggal.

12 Indah Permatasari Suardi, Syahrul Ramadhan, dan Yasnur Asri, "Pemerolehan Bahasa Pertama pada Anak Usia Dini," Jurnal Obsesi : Jurnal Pendidikan Anak Usia Dini 3, no. 1 (2019): 265, https://doi.org/10.31004/obsesi.v3i1.160.
} 
Mahajani, pemerolehan bahasa merupakan proses pemahaman dan proses hasil berbahasa pada manusia. ${ }^{13}$ Dalam perkembangannya banyak para ahli yang yang menggunakan istilah akuisisi bahasa dalam hal proses pemerolehan bahasa kedua. ${ }^{14}$ Sebagaimana jika ditilik dari bentuk akuisi atau permerolehan bahasa, ada bentuk pemerolehan bahasa pertama atau lughotu al um (first lenguage), dan juga ada bentuk pemerolehan bahasa kedua atau al lughoh al ajnabiyah (second language). ${ }^{15}$ Dalam penelitian ini yang dimaksud akuisisi bahasa adalah proses pemerolehan bahasa kedua yaitu kaitannya dengan pemerolehan bahasa Arab yang dilakukan pada pondok pesantren Madinah Karya Tani Labuhan Meringgai.

Pemerolehan bahasa kedua khususnya bahasa-bahasa asing yang dipelajari di lembaga-lembaga pendidikan tentu dipengaruhi oleh banyak faktor. Hal ini karena banyak komponen yang yang terlibah dalam suatu lembaga pendidikan, baik faktor yang berasal dari internal peserta didik atau faktor eksternal dari peserta didik. Di antara faktor-faktor yang mempengaruhi proses pemerolehan bahasa kedua yaitu: 1) Faktor motivasi; di antara faktor yang mempengaruhi akuisisi bahasa kedua adalah motivasi peserta didik. Motivasi peserta didik bisa muncul dari internal peserta didik atau eksternalnya yang disebut motivasi intrinsik dan ekstrinsik. 2) Faktor usia; dalam hal usia banyak teori yang beranggapan bahwa usia anak-anak akan lebih mudah menerima bahasa kedua dibandingkan dengan usia dewasa. 3) Faktor penyajian formal; dalam proses akuisisi bahasa dapat melalui proses naturalistik dan dapat juga dengan proses pembelajaran secara formal. Umumnya di Indonesia akuisisi bahasa asing khususnya bahasa Arab melalui proses pembelajaran secara formal. 4) Faktor bahasa pertama; khususnya bahasa arab sudah banyak kosakata yang relative sama dalam beberapa hal baik bunyi maupun artinya. Hal ini tentu memiliki pengaruh terhadap pemerolehan bahasa Arab bagi para peserta didik yang mempelajarinya. 5) Faktor lingkungan; terkait dengan lingkungan bahasa adalah apa yang dilihat dan didengar peserta didik. Apabila peserta didik tinggal di tempat yang dapat mengakses baik melalui penglihatan ataupun pendengaran yang berbahasa Arab maka akan mempengaruhi pemerolehan bahasanya. ${ }^{16}$

Tujuan penelitian ini ingin mengkaji tentang akuisisi bahasa Arab santri dan faktor utama pendukung akuisisi bahasa Arab santri pondok pesantren Madinah. Adapun kajian-kajian sebelumnya yang berkitan dengan penelitan ini di antaranya yaitu; 1) Pembelajaran Bahasa Arab Sebagai Bahasa Kedua; kajian pustaka oleh Doni handriawan. Hasil dari kajiannya menyatakan bahwa belajar bahasa asing

13 Tri Mahajani dan Ruyatul Hilal Muhtar, "Pemerolehan Bahasa Dan Penggunaan Bahasa Anak Usia Sekolah Dasar," JPI (Jurnal Pendidikan Indonesia): Jurnal Ilmiah Pendidikan 5, no. 3 (2019): 170, https://jurnal.uns.ac.id/jpi/article/view/46477.

${ }^{14}$ Abdul Chaer, Psikolinguistik (Kajian Teoritik) (Jakarta: Rineka Cipta, 2003), 167. 2013), 86.

${ }^{15}$ Iskandarwassid dan Dadang Suhendar, Strategi Pembelajaran Bahasa (Bandung: Rosda Karya,

${ }^{16}$ Chaer, Psikolinguistik (Kajian Teoritik), 251. 
terlebih bahasa Arab sebagai bahasa kedua, tidak bisa dielakkan mempunyai kendala dan hambatan yang tidak sedikit. Namun demikian dengan keberadaan kita di Indonesia yang "notabene" seorang muslim harus bisa "disiasati" sebagai modal pendukung kita dalam belajar dan mengajarkan bahasa Arab. Salah satunya adalah agar orientasinya diarahkan kepada pengembangan ilmu pengetahuan. ${ }^{17}$ 2) Bi'ah Lughowiyah dan Pemerolehan Bahasa; kajian pustaka oleh A. Hidayat. Hasil kajiannya menyatakan bahwa pembenahan terhadap pembelajaran bahasa Arab merupakan suatu keharusan, baik dari manajemen, kurikulum, proses, maupun evaluasinya. Karena tanpa rekonstruksi terhadap pembelajaran bahasa Arab pengetahuan bahasa Arab yang mempengaruhi pengetahuan keislaman para peserta didik akan semakin menghawatirkan. Salah satu upaya dalam merekonstruksi pembelajaran bahasa Arab adalah dengan menciptakan lingkungan bahasa. ${ }^{18}$ 3) Bahasa Arab sebagai Bahasa kedua (Kajian Teoritis Pemerolehan Bahasa Arab pada Siswa Non-Native); Kajian pustaka oleh Ahmad Habibi Syahid. Hasil kajiannya menyatakan bahwa proses pemerolehan bahasa dapat terjadi dalam otak seseorang ketika dia memperoleh bahasa pertamanya. Sedangkan pemerolehan bahasa kedua dapat terjadi seperti pada pemerolehan bahasa pertama, akan tetapi juga bisa terjadi melalui proses belajar. ${ }^{19}$ 4) Psikologi Belajar Bahasa; kajian pustaka oleh Dudung Hamdun. Hasil kajiannya menyatakan bahwa manusia dimanapun juga pasti akan dapat menguasai, atau lebih tepatnya memperoleh bahasa asalkan dia tumbuh dalam suatu masyarakat. Proses pemerolehan ini merupakan suatu hal yang konroversial di antara para ahli bahasa. Dari kajian-kajian yang sudah dilakukan tampak belum ada yang membahas tentang akuisisi bahasa Arab, sehingga menjadi penting untuk dilakukan. ${ }^{20}$

\section{Metode Penelitian}

Penelitian ini merupakan penelitian kualitatif lapangan. Untuk pengumpulan data menggunakan metode observasi, metode wawancara, dan metode dokumentasi. Teknik analisis data yang dilakukan melalui reduksi data, display data, mengambil kesimpulan dan verifikasi. Data yang diperoleh dalam penelitian ini berasal dari subjek penelitian, yaitu para ustad dan santri Pondok Pesantren

17 Dony Handriawan, "Mempertegas Kembali Arah Pembelajaran Bahasa Arab (Perspektif Budaya Terhadap Tradisi Belajar Bahasa Arab Di Indonesia)," al Mahāra: Jurnal Pendidikan Bahasa Arab 1, no. 1 (2015): 53-78, https://doi.org/10.14421/almahara.2015.011-03.

18 Hidayat, "Bi'ah Lughowiyah (Lingkungan Berbahasa) Dan Pemerolehan Bahasa (Tinjauan Tentang Urgensi Lingkungan Berbahasa Dalam Pemerolehan Bahasa)."

19 Ahmad Habibi Syahid, "Bahasa Arab Sebagai Bahasa Kedua (Kajian Teoretis Pemerolehan Bahasa Arab pada Siswa Non-Native)," Arabiyat : Jurnal Pendidikan Bahasa Arab dan Kebahasaaraban 2, no. 1 (2015): 86-97, https://doi.org/10.15408/a.v2i1.1797.

20 Dudung Hamdun, "Psikologi Belajar Bahasa," Al-Arabiyah 2, no. 2 (2006): 73-91, http://digilib.uin-suka.ac.id/id/eprint/7958/. 
Madinah Karya Tani Labuhan Meringgai. Kajian ini mendiskripsikan tentang; 1) proses pembelajaran bahasa Arab, 2) proses akuisisi bahasa Arab (iktisaab al lughah al Arabiyah), 3) relepansi teori akuisisi dalam perspektif psikolinguistik dengan proses pembelajaran bahasa Arab, dan 4) kelebihan dan kelemahan proses akuisisi bahasa Arab di Pondok Pesantren Madinah Karya Tani Labuhan Maringgai. Penelitian ini juga ingin mendiskripsikan tentang faktor usia santri dalam pemerolehan bahasa Arab.

\section{Hasil dan Pembahasan \\ Proses Pembelajaran Bahasa arab}

Sebagai sebuah lembaga formal pondok pesantren Madinah di Labuhan Maringgai lampung Timur secara umum pembelajarannya memiliki komponenkomponen pembelajaran sebagaimana lembaga formal lainnya. Lembaga ini memiliki kurikulum, pendidik, metode dan media pembelajaran serta perangkat evaluasi. Dalam penelitian ini data-data yang berkaitan dengan komponenkomponen tersebut merupakan data-data sekunder, adapun data-data primer berkaitan dengan perangakat analisis yang berupa motivasi santri, usia santri, penyajian pembelajaran bahasa Arab, bahasa pertama dan lingkungan santri.

\section{Komponen-komponen pembelajaran}

a. Kurikulum; Kurikulum pondok pesantren Madinah mengacu pada kurikulum pondok pesantren Gontor karena lembaga ini diprakarsai oleh alumni-alumni pondok pesantren Gontor. Untuk pelajaran Muthala'ah (Membaca bahasa Arab) adalah mata pelajaran SD di Mesir. Adapun pelajaran Nahwu (Tata bahasa Arab) juga menggunakan al Nahwu al Wadhih berbeda dengan kitab-kitab nahwu yang diajarkan di pondok-pondok pesantren salaf yang mengajarkan kitab al Jurumiyah dan Alfiyah.

b. Pendidik (Ustadz); para pendidik tau ustadz ada yang berstatus guru tetap dan ada yang berstatus pengabdian. Ustad atau ustadzah pengabdian adalah santri senior yang sudah menyelesaikan pendidikannya selama 6 tahun mulai dari MTs sampai MA mereka wajib mengabdi mengajarkan ilmunya selama satu tahun di pondok pesantren Madinah.

c. Metode

1) Al-muhadatsah al-yaumiyyah atau bercakap-cakap dalam bahasa arab. Kegiatan ini dilaksanakan dua kali dalam satu minggu setelah shalat subuh atau sebelum lari pagi. Setiap santri mencari pasangan bicaranya masingmasing kemudian harus berbincang-bincang dalam bahasa arab. Sementara pengurus santri mengawasinya. Dan seluruh santri diwajibkan membawa kutaib atau buku saku yang didalamnya berisi mufradat atau kosa kata bahasa arab. Hal ini digunakan sebagai kesempatan bagi para ustad untuk memperbaiki tata bahasa yang digunakan santri dan juga pemilihan kosakata dalam percakapan. 
2) Al-ilqaa al-mufradaat atau penyampaian kosa kata. Kegiatan ini juga dilakukan pada pagi hari setelah membaca al-Qur'an. Setiap santri berkumpul perkamar, kemudian para pengurus santri menyampaikan beberapa kosa kata (mufrodat) dalam bahasa arab. Tidak hanya itu, pengurus juga harus memahamkan arti kosa kata tersebut tanpa memberi arti kosa kata itu. cukup dengan menaruhnya di dalam kalimat atau mempraktekannya jika memungkinkan. Dan pada waktu itu juga, santri harus menghafal kosa kata itu. sewaktu-waktu, pengurus akan menanyakannya, jika tidak bisa maka akan diberi hukuman. Dalam hal ini tampaknya basis pembelajaran kosakatanya berbasis metode mubasyiroh dimana dalam pembelajaran seorang pendidik/ustad senantiasa menggunakan bahasa Arab dalam menyampaikan pelajaran.

3) Al-khithaabah al-Minbariyah atau latihan pidato bahasa arab. Latihan pidato di Pondok pesantren Madinah terbagi menjadi 3 bahasa yaitu arab, inggris dan indonesia. Setiap santri akan menerima giliran pidato 2 minggu sekali. Dan setiap santri wajib membuat naskah pidato itu dengan tanda tangan pembimbing dan bagian pengajaran sehari sebelum ia tampil. Dalam pembelajaran pidato bukan hanya melatih berbicara bahasa Arab tapi juga melatih mental santri untuk dapat berbicara di depan para audien.

4) Al-insya al-Yaumiy atau membuat karangan dalam bahasa arab. Kegiatan ini dilakukan 2 minggu sekali. Santri kelas 6 diwajibkan membuat insya yang dikumpulkan di hari tertentu kepada ketua kelasnya masing-masing yang nantinya dikumpulkan ke bagian KMI. Kemampuan insya' dibina di kelas tinggi karen kemampuan ini merupakan kemampuan tertinggi dalam kemahiran berbahasa Arab.

5) Penyampaian pelajaran di Pondok Madinah menggunakan bahasa arab kecuali pelajaran umum. Ini bertujuan sebagai pendukung peningkatan kebahasaan khususnya bahasa arab.

d. Media; dalam aktivitas belajar mengajar khususnya di kelas ustad ataupun ustadzah menggunakan media-media yang bersifat konfensional dalam pembelajaran, seperti papan tulis dan alat-alat peraga. Khusus pengembangan kemampuan bahasa Arab lembaga ini sudah memiliki laboratorium bahasa yang digunakan untuk melatih kemampuan mendengar (istima') dan kemampuan berbicara (Kalam).

e. Evaluasi; Untuk pendidikan formal Evaluasi dilaksanakan bersifat formal yaitu sebagaimana dilaksanakan di sekolah-sekolah formal lainnya. Sedangakan di luar kelas dilaksanakan di setiap pembelajaran, seperti tes kosakata (mufrodat), pidato (Khithabah)) dan mengarang (Insya').

f. Waktu belajar; Waktu belajar untuk kegiatan pembelajaran formal sama dengan sekolah formal yang lain yaitu dimulai dari jam 07.15 sampai dengan jam 12.30. sedangkan untuk di luar kelas mulai dari pagi hari setelah shalat subuh dan 
siang hari setelah shalat dhuhur, istirahat dan makan siang. Adapun malam hari terdapat jadwal setelah magrib dan setelah shalat isya'.

g. Motivasi santri

Dari data di lapangan ditemukan bahwa motivasi santri cenderung banyak dari luar (ekstrinsik). Mayoritas santri sudah pernah mendapatkan hukuman karena tidak menggunakan bahasa Arab. Setiap harinya banyak santri yang mendapatkan hukuman di antaranya dengan dihukum berlari mengelilingi lapangan.

h. Usia santri

Sekolah yang diselenggarakan di pondok pesantren madinah dimulai dari sekolah setingkat SLTP, maka usia santri yang belajar dimulai dari usia rata-rata 12-13 tahuan dan selesai pada usia 18-19 tahun.

i. Penyajian pelajaran bahasa Arab

Penyajian pembelajaran bahasa Arab mulai dari setelah melaksanakan shalat subuh hingga malam (bakda isya). Penyajian pembelajaran bahasa Arab yang bersifat formal dilaksanakan di luar kelas, seperti pemberian kosakata (mufradat), berpidato dengan bahasa Arab (alKhithabah), kewajiban praktek bicara bahasa Arab sehari-hari. Adapun yang di dalam kelas formal adalah pembelajaran bahasa Arab dengan mengikuti kurikulum yang diwajibkan oleh pondok pesantren.

j. Bahasa pertama santri

Sebelum santri diwajib menggunakan bahasa Arab dalam aktivitas sehari-hari selama satu tahun santri diwajibkan menggunakan bahasa Indonesia, mereka tidak diperkenankan menggunakan bahasa daerah masing-masing.

k. Lingkungan santri

Komponen lingkungan santri adalah para pengurus pondok pesantren, para ustad, senior yang mengabdi, pengurus konsumsi pondok pesantren.

\section{Akuisisi Bahasa Arab}

Dari hasil survey pada kegiatan pembelajaran dan wawancara kepada para ustad, pengurus dan para santri dapat diklasifikasikan akuisisi bahasa Arab santri melalui beberapa sumber sebagai berikut;

a. Bersumber dari pembelajaran di kelas; pembelajaran di kelas sebagaimana di sekolah lain, bahasa Arab diajarkan di samping pelajaran-pelajaran yang lain yang diwajibkan dalam kurikulum nasional.

b. Bersumber dari kegiatan di luar kelas; di luar kelas santri mendapatkan penguatan-penguatan khususnya penguatan kosakata, praktek bicara terbimbing, dan berpidato bahasa Arab.

c. Bersumber dari sesama santri di luar kelas; sesama santri di luar kelas diwajibkan berbahasa Arab, ini dilakukan setiap waktu dalam setiap percakapan atau kegiatan komunikasi dalam interaksi sosial sesama santri. 
d. Bersumber dari para pengurus dan ustad di luar kelas; selain berinteraksi dengan sesama santri dengan menggunakan bahasa Arab para pengurus dan ustad juga senantiasa menggunakan bahasa Arab dalam berkomunikasi baik sesama pengurus dan ustad juga dengan para santri.

\section{Diskusi Mengenai Relevansi Teori Akuisi dalam Psikolinguistik dengan Akuisisi Bahasa Arab Santri}

a. Motivasi mempengaruhi proses akuisisi bahasa Arab santri pondok pesantren madinah; Berdasarkan hasil survey dan wawancara dapat disimpulkan bahwa motivasi santri untuk berbicara bahasa Arab banyak dipengaruhi oleh motivasi yang bersifat eksternal. Walaupun motivasi santri berasal dari eksternal tampaknya hukuman-hukuman yang dilaksanakan cukup memotifasi santri untuk menggunakan bahasa Arab dan hukuman-hukuman tersebut cukup efektif dalam menggerakkan santri untuk tidak melanggar. Hal ini sesuai dengan pendapat Abdul Khair yang mengatakan bahwa di antara faktor yang mempengaruhi akuisisi bahasa kedua adalah motivasi peserta didik.

b. Usia mempengaruhi proses akuisisi bahasa Arab santri pondok pesantren madinah; usia santri yang berkisar antar 12 sampai dengan 18 tahun dapat dikategorikan usia anak-anak dan remaja. Kondisi ini sangat efektif dalam proses akusisi bahasa Arab di pondok pesantren Madinah sbagaimana dinyatakan dalam hal usia, banyak teori yang beranggapan bahwa usia anakanak akan lebih mudah menerima bahasa kedua dibandingkan dengan usia dewasa.

c. Penyajian pembelajaran di pondok pesantren Madinah sudah memenuhi persyaratan dalam akuisi bahasa asing khususnya Arab. Penyajian pembelajaran bahasa Arab sudah menggunakan dua proses yaitu secara naturalistik dengan membangun lingkungan bahasa secara rekayasa dan penyajian secara formal yang dilaksnakan secara klasikal dan mengikuti kurikulum formal. Sebagaimana dinyatakan bahwa dalam Faktor penyajian formal dalam proses akuisisi bahasa dapat melalui proses naturalistik dan dapat juga dengan proses pembelajaran secara formal. Kendatipun dinyatakan pula bahwa umumnya di Indonesia akuisisi bahasa asing khususnya bahasa Arab melalui proses pembelajaran secara formal.

d. Bahasa pertama santri yang beragam yang berupa bahasa daerah masingmasing santri kiranya sudah dilakukan antisipasi dengan mewajibkan santri berbicara bahasa Indonesia di tahun pertama mereka dididik di pondok pesantren. Hal ini juga mendukung penguasan bahasa Arab santri karena dalam selain tidak terganggu oleh bahasa daerah masing-masing santri juga dapat lebih fokus hanya pada bahasa Indonesia dan bahasa Arab yang akan dipelajaran terlebih dalam bahasa Indonesia sudah banyak menyerap bahasa asing khususnya bahasa arab sudah banyak kosakata yang relative sama dalam beberapa hal baik bunyi maupun artinya dan hal ini tentu memiliki pengaruh 
terhadap pemerolehan bahasa Arab bagi para peserta didik yang mempelajarinya.

e. Lingkungan yang dibangun dengan basis bahasa Arab ternya berpengaruh signifikan bagi santri dalam penguasaan bahasa Arab karena situasi lingkungan bahasa akan terkait dengan apa yang dilihat dan didengar peserta didik. Apabila peserta didik tinggal di tempat yang dapat mengakses baik melalui penglihatan ataupun pendengaran yang berbahasa Arab maka akan mempengaruhi pemerolehan bahasanya. ${ }^{21}$

\section{Kendala Proses Akuisisi Bahasa Arab di Pondok Pesantren Modern Madinah}

Dari hasil wawancara dan pengamatan yang dilakukan kiranya ada beberapa kendala yang terdapat dalam proses akuisisi bahasa Arab di pondok pesantren Madinah Karyatani Labuhan Maringgai, di antaranya yaitu:

a. Motivasi santri masih banyak berasal dari luar diri para santri. Banyak santri setiap harinya mendapatkan hukuman karena "melanggar" tidak menggunakan bahasa Arab dalam percakapan sehari-hari.

b. Lingkungan bahasa sering tidak kondusif dan memperlambat proses akuisisi bahasa Arab karena banyak santri yang kurang disiplin dalam menggunakan bahasa Arab dalam komunikasi sehari-hari.

\section{Kelebihan dan kelemahan Proses Akuisisi Bahasa Arab Santri Pondok Pesantren Madinah}

Di antara kelebihan proses akuisisi bahasa Arab santri pondok pesntren modern Madinah adalah;

a. Santri dapat menjalani proses akuisisi bahasa Arab bukan hanya secara formal sebagaimana di lembaga-lembaga lain yang menyajikan pembelajaran bahasa Arab akan tetapi santri dapat menjalani proses akuisisi bahasa Arab secara natural dengan berada di lingkungan bahasa Arab yang setiap waktu mendengar dan melihat orang-orang berbicara bahasa Arab.

b. Proses akuisisi bahasa Arab santri pondok pesntren modern Madinah menjadikan santri memiliki percaya diri dalam berbicara bahasa Arab. Hal ini karena penyajian pembelajaran yang berbasis praktik menjadikan santri tidak terlalu berfikir mengenai tata bahasa (Nahwu) dan juga pemilihan kata (Sharaf). Santri lebih banyak belajar dari apa yang didengar di lingkungan pondok pesantren yang komunitasnya berbicara dengan menggunakan bahasa Arab.

Adapun kelemahannya jika akuisisi bahasa Arab mencakup pemahaman lingustiknya maka kiranya santri tidak memiliki bekal lebih banyak dari kemampuan berbicaranya. Pengalaman dan penguasaan membaca berbagai kitab khusnya yang berkaitan dengan nahwu dan sharaf tidak lebih banyak dibandingkan santri yang belajar di pondok pesantren salaf pada umumnya.

\footnotetext{
${ }^{21}$ Chaer, Psikolinguistik (Kajian Teoritik), 251.
} 


\section{Kesimpulan}

Pondok pesantren modern Madinah Karyatani Labuhan Maringgai memiliki kurikulum, sistem, dan metode yang mengacu pada pondok pesantren Gontor. Distingsi dari pondok pesantren ini adalah kemampuan komunikasi bahasa asing, yaitu bahasa Arab dan bahasa Inggris. Dari hasil kajian yang dilakukan dapat disimpulkan bahwa akuisi bahasa asing khususnya bahasa Arab santri pondok pesantren modern Madinah Karyatani Labuhan Maringgai dilakukan melalui penyajian formal dan naturalistik. Untuk faktor-faktor yang mempengaruhi proses akuisisi bahasa Arab terdapat kendala pada motivasi santri yang berpengaruh juga pada lingkungan bahasa Arab yang kurang kondusif. Adapun yang berkaitan dengan faktor usia, penyajian pembelajaran dan bahasa pertama santri telah dikondisikan dan sesuai dengan proses akuisisi bahasa asing yang ideal dalamperspektif psikolinguistik. Usia anak-anak hingga remaja merupakan usia ideal untuk melakukan proses akuisisi bahasa asing, penyajian pembelajaran yang lengkap secara formal dan naturalistik, serta mengkondisikan bahasa pertama dengan berbahasa Arab di tahun pertama santri belajar di pondok pesantren.

\section{Daftar Pustaka}

Chaer, Abdul. Psikolinguistik (Kajian Teoritik). Jakarta: Rineka Cipta, 2003.

Hamdun, Dudung. "Psikologi Belajar Bahasa." Al-Arabiyah 2, no. 2 (2006): 73-91. http://digilib.uin-suka.ac.id/id/eprint/7958/.

Handriawan, Dony. "Mempertegas Kembali Arah Pembelajaran Bahasa Arab (Perspektif Budaya Terhadap Tradisi Belajar Bahasa Arab Di Indonesia)." al Mahāra: Jurnal Pendidikan Bahasa Arab 1, no. 1 (2015): 53-78. https://doi.org/10.14421/almahara.2015.011-03.

Hermawan, Acep. Metodologi Pembelajaran Bahasa Arab. Bandung: Remaja Rosdakarya, 2011.

Hidayat, A. "Bi'ah Lughowiyah (Lingkungan Berbahasa) Dan Pemerolehan Bahasa

(Tinjauan Tentang Urgensi Lingkungan Berbahasa Dalam Pemerolehan Bahasa)." An-Nida' 37, no. 1 (2012): 35-44. http://ejournal.uinsuska.ac.id/index.php/Anida/article/view/311.

Iskandarwassid, dan Dadang Suhendar. Strategi Pembelajaran Bahasa. Bandung: Rosda Karya, 2013.

Mahajani, Tri, dan Ruyatul Hilal Muhtar. "Pemerolehan Bahasa Dan Penggunaan

Bahasa Anak Usia Sekolah Dasar." JPI (Jurnal Pendidikan Indonesia): Jurnal $\begin{array}{llllll}\text { Ilmiah Pendidikan } & \text { 5, } & \text { no. } & 3 & \text { (2019): } & 170 .\end{array}$ https://jurnal.uns.ac.id/jpi/article/view/46477.

Mansyur, Abdul Majid Sayid Ahmad. Ilmu Al-Lughoh Al-Nafsi. Riyadh: Jami'ah Mulk Su'udi, 1982.

Mu'in, Abdul, dan Dony Handriawan. "Pembelajaran Bahasa Arab Sebagai Bahasa Kedua." Al-Ittijaah 4, no. 2 (2012): 144. 
Suardi, Indah Permatasari, Syahrul Ramadhan, dan Yasnur Asri. "Pemerolehan Bahasa Pertama pada Anak Usia Dini." Jurnal Obsesi : Jurnal Pendidikan Anak Usia Dini 3, no. 1 (2019): 265. https://doi.org/10.31004/obsesi.v3i1.160.

Sujinah. Bahasa Indonesia. Surabaya: UM Surabaya Pablishing, 2018.

Sumanto, Edi. "Hubungan Filsafat Dengan Bahasa." El-Afkar: Jurnal Pemikiran Keislaman Dan Tafsir Hadis 6, no. 1 (2017): 19-30. https://ejournal.iainbengkulu.ac.id/index.php/elafkar/article/view/1236.

Syahid, Ahmad Habibi. "Bahasa Arab Sebagai Bahasa Kedua (Kajian Teoretis Pemerolehan Bahasa Arab pada Siswa Non-Native)." Arabiyat: Jurnal Pendidikan Bahasa Arab dan Kebahasaaraban 2, no. 1 (2015): 86-97. https://doi.org/10.15408/a.v2i1.1797.

Zaidan, Jurji. Al-Falsafah Al-Lughowiyah. Beirut: Daaru Al-Jiil, 1904. 